\title{
Literacy Strategy Journal: Planning Literacy Instruction in a Liberal Arts College
}

\author{
Antonio Causarano ${ }^{1}$ \\ ${ }^{1}$ Education, Alfred University, USA \\ Correspondence: Antonio Causarano, 1Saxon Drive Myers Hall Room 348 Alfred, NY 14802, USA. Tel: \\ 1-607-871-2808. E-mail: causarano@alfred.edu
}

Received: June 7, $2013 \quad$ Accepted: July 5, $2013 \quad$ Online Published: August 14, 2013

doi:10.5539/jel.v2n3p111 URL: http://dx.doi.org/10.5539/jel.v2n3p111

\begin{abstract}
This paper discusses the importance of writing, developing, and implementing a literacy strategy journal as a junior faculty teaching literacy courses in a University in the United States. The analysis of the content of the literacy strategy journal is carried out by applying a Bakhtinian dialogic framework to become aware and understand how dialogicality between the instructor and the content of the literacy strategy journal supported a systematic and in depth self-reflection aimed to improve teaching and pedagogy in the literacy courses taught. The author wants to demonstrate that the literacy strategy journal is not a static object, a legal pad notebook with words written down in a linear fashion but a dynamic site of self-reflection and growth for improving teaching and learning in literacy courses in higher education. The literacy strategy journal used by the author is a third space for self-reflection and pedagogical growth paramount to prepare literacy teachers for the $21^{\text {st }}$ century in K-12 schools in the United States.
\end{abstract}

Keywords: literacy, self-reflective practice, dialogic theory, learning journals

\section{Introduction}

In the field of education and reflective practice learning journals have been extensively used by educators as cognitive and practical tools for professional development and growth (Bolton, 2010). Moon (2006) writes that "A learning journal is essentially a vehicle for reflection" (p. 1). The importance of keeping a learning journal lies in the opportunity to make the invisible process of reflective thinking visible in the form of narrative on paper or other media to support reflective thinking in educators or professionals in the field of teaching and learning. LaBoskey (1994) encourages teachers and teacher educators to develop a systematic reflection on their own teaching and professional development by using narrative and journaling as the site or repository of an ever-growing thinking and refinement in the field of education.

A learning journal as reflective tool is a guide, a map that the reflective educator can use to circle back times and times again on what worked or what needs to be improved in his/her teaching profession by a systematic and continuous dialogue with the learning self. It is an ongoing conversation with the professional self engaged in refining the theoretical and pedagogical tools of a discipline or field of study (Attard, 2008). The narrative form in a learning journal is a dynamic process where the mind of the reflective practitioner is engaged in a process of dialogic feedback with the written word continuously transforming the underlined meaning of the narrative through time (Richardson, 2001).

This paper explores the importance of keeping a Literacy Strategy Journal as a junior faculty in a Liberal Arts College in the United States to reflect on the teaching processes of the author instructing pre-service teachers in literacy courses at the undergraduate and graduate levels. A Bakhtinian dialogic framework will be used to analyze the author's Literacy Strategy Journal to bring to the fore the complexity of self-reflective practice in teaching literacy to pre-service teachers and how this dialogical process set the conditions for intellectual and pedagogical growth as a teacher educator.

\section{Theoretical Framework}

Bakhtin $(1981,1984)$ examines the social construction of language and meaning as well as the importance of language in creating dialogic connections between the self and others in specific socio-historical and sociocultural conditions. Bakhtin $(1981,1984)$ claims that any kind of learning is social since individuals live 
and interact in a social and cultural environment where language is the primary and most important system where the process of learning happens and unfolds. Bazerman (2004) points out that Bakhtin's preoccupation with language as a social and cultural phenomenon has paramount importance for education since language in social and historical contexts becomes the repository of experiences educators can access and reflect upon to refine their thinking and practice in educational settings.

Bakhtin (1986) argues that the study of language as a social and historical phenomenon must be analyzed in the formation of meaning that emerges from specific sociocultural and sociohistorical conditions of language individuals use in a community of speakers. Bakhtin/Volosinov (1986) writes "Language acquires life and historically evolves... in concrete verbal communication and not in the abstract linguistic system of language, nor in the individual psyche of the speakers" (p. 95). According to Bakhtin $(1981,1984)$ words are relational because of the intrinsic nature of language viewed in its concrete social and historical condition. Language for Bakhtin $(1981,1984)$ is a dynamic site of meaning formation through the continuous reworking of the word used by different speakers in a community and the changing nature of meaning creates the conditions for the changing of ideas and perceptions about a specific object of the speaker's experience through time.

Language is a dialogic system between the self and an objective experience that the self, the subject experiences not just here and now but through social and historical developments in particular sociohistorical and sociocultural conditions. Bakhtin (1984a) writes

The word is not a material thing but rather the eternally mobile, eternally fickle medium of dialogic interaction. It never gravitates toward a single consciousness or a single voice. The life of the word is contained in its transfer from one mouth to another, from one context to another context, from one social collective to another, from one generation to another generation. In this process the word does not forget his own path and cannot completely free itself from the power of those concrete contexts into which it has entered (p. 201).

The importance of the word as a dialogic process embedded in social and historical conditions holds a crucial importance for reflective practice in education and the use of journals as sites of reflection between the self and an objective experience, the intended other of our experience (Hallman, 2011). Bakhtin's insistence on the other as a site of dialogic process can be contextualized within a reflective practice approach where the self reflects upon a concrete experience found in particular social and historical conditions. Self-reflection does not happen in a vacuum but unfolds and develops due to its function of illuminating an experience that the reflective practitioner is experiencing with the goal to understand it in a systematic and specific way. Fendler (2003) claims that reflection is never a neutral process but is always embedded in social and historical conditions experienced by the self.

The importance of using Bakhtin to analyze the narrative in my Literacy Strategy Journal is due to my focus in understanding how my experience as literacy instructor and reflective practitioner is always at the crossroads of my own experience and the objective experience in teaching literacy courses. In listening to the students in the courses I have become aware of and understood the pluses and minuses of my ability to teach and support pre-service literacy teachers in K-12 education. As Hallman (2011) claims,

A Bakhtinian focus on the relationship between speaker and intended 'other' is particularly relevant to the study of reflective practice as dialogic, as it reminds us that the premise behind the development of reflective practices is the urge to action. Teachers reflect in order to act-either on themselves, on others, or on their practice. Text is viewed as always in relation to and in response to an intended 'other." Bakhtin believed that we are always intimately connected to the spatial and temporal contexts in which we live and these connections are how we articulate who we are, as well as our relationship to others (Holquist, 1990). In considering text to not only rhetorical, but to be dialogically rhetorical, Bakhtin highlights the relationship to an intended 'other' (p. 535) (Emphasis in original).

It is this nature of text as dialogical between the self and the intended other that constitutes the core of my analysis of the Literacy Strategy Journal used to open up new spaces for self reflection and professional growth as junior faculty in a Liberal Arts College. Hallman (2011) points out an important aspect of self-reflection through the use of text that opens up new directions in the analysis of self-reflective practice in narrative textual forms. Hallman (2011) claims that in a Bakhtinian view text is always bi-directional or is constructed in a contact zone between the self and the other in particular sociohistorical and sociocultural conditions.

\section{Personal Journey}

I started teaching in a Liberal Arts College in August 2011 after three years of teaching special education in a middle school in a large urban district in the Southwest United States. I was hired to teach graduate and 
undergraduate courses in literacy in content areas at the secondary level and courses in special education for teaching students in inclusive settings. I moved from the Southwest to the Northeast, New York State, and began to settle down in the new place by developing my syllabi, getting familiar with the Division of Education and the requirements of the State Department of Education in New York State to align my syllabi with the pedagogical core and standards for teaching courses in literacy and special education, and reading the textbooks to organize the sequence and delivery of instruction.

While I was developing the syllabi and the material for the literacy courses to teach, I began to keep a journal by jotting down some ideas that were emerging while planning my instruction. The journal at the beginning was just a yellow legal pad with only dates and the course name and number but without any organization on what to write and what sequence or rationale I wanted to use in keeping a record of my thoughts, feelings about the courses and a reflective corner in the journal. Only when I began to teach the courses in literacy and special education, did the journal go through a qualitative transformation in form and content (Boud, 2001).

The journal was organized into two reflective sections: (a) the Process component and (b) the Research component. The former was the part in which I jotted down my thoughts about teaching emerging naturally from the literacy courses. The latter was the part in which an action plan was designed to support the students in the course to become better literacy teachers. The dialogicality in the journal is represented by this on-going conversation between process and research to improve literacy instruction for pre-service teachers in the courses.

I revisited the first pages of my journal and I made the decision to use it as a systematic tool for reflective practice to monitor my growth as a junior faculty and to create a virtual loop of reflection between my perception of teaching college courses and the feedback from my students along the semester. I began with the name I wanted to give my reflective journal and deiced that Literacy Strategy Journal was appropriate since the reflections emerging from the journal were focused on how to improve literacy instruction in the undergraduate and graduate courses I was teaching (Epp, 2008).

The second step was to systematically think about a rationale for the process, the research component and applied knowledge of the journal to refine my self-reflective journey for teaching. The Literacy Strategy Journal created a dialogic loop between the instructor and the courses in literacy I was teaching since my goal was not just to self-reflect but to use self-reflection to connect with the live fabric of the classroom. I analyzed the feedback coming from my students as guidelines to improve my teaching based on a dialogic use of the Literacy Strategy Journal (Bakhtin, 1981). In so doing, the blueprint for self-reflection by using a dialogic framework was laid out and the format of the journal was kept simple by putting the name of the literacy courses I was teaching and the thoughts emerging from the course in a dialogic/polyphonic mode (Bakhtin, 1986).

\section{The Rationale for the Literacy Strategy Journal}

The first page of the Literacy Strategy Journal begins with my rationale on the importance of setting the stage for good teaching. I wrote,

The "secret" of good teaching lies in aligning and contextualizing the activities for the students to activate their prior knowledge and acquire and retain the knowledge presented in the flow of instruction. A good instructor must design activities and prepare material that stimulate, support, and refine students' analytical thinking by systematically connecting the activities with the core content of the literacy course. Also, the instructor must become an attentive listener to create a virtual loop in the flow of instruction with the students to record students' feedback and create a dialogue between the good intentions of teaching and what needs to be adjusted according to the students' needs and their ability to connect to the content of the course (p. 1).

The rationale was the barometer of my instruction contextualized within a dialogic self-reflective practice (Bakhtin, 1984). The notes I was jotting down and the thoughts emerging from this dialogic mode were always analyzed on the background of the rationale I wrote at the beginning of my journal. This constant circling back to the rationale refined and fine-tuned my Literacy Strategy Journal. I added the Process component to it to develop the ability to connect my theoretical thinking to the teaching contexts of the literacy course. I was able to refocus my instruction by a better analysis of the reflective narrative in the journal (Cornish and Cantor, 2008).

In the Process component of my Literacy Strategy Journal I wrote,

The instructor must carefully read the sequence of presentation of the content and decide the medium of presentation (visual or other) and make a decision where he wants to insert the activities to support students' analytical thinking and learning of the material in the course. This part of the instruction is crucial because it determines the emphasis the instructor wants to put on the specific content knowledge the students will work on 
during the class period. Also, the place where the activities are presented to the students in the flow of instruction have the function of weaving the content and the activity at the theoretical and methodological level and create a balance between theory and practice in literacy instruction (p. 2).

The Process component was the weaver of my dialogic self-reflective practice because theory and methodology of instruction were intertwined within a dialogic self-reflective narrative. The Process component was the connector between my analytical/theoretical thinking and the feedback coming from the bottom-up, the courses I was teaching, to continuously self-regulate my reflective thinking on how to improve my instruction (Connor-Greene, 2000).

The Research component of the Literacy Strategy Journal was the place where I was sifting through the narrative emerging from the rationale and the process components to use effective data in teaching the literacy courses. The Research component was constructed and rationalized as follows

The instructor must carry out a systematic and extensive research to find good material to develop and propose activities that support learning in the flow of instruction. The activities and related strategies must always balance aural, visual, and sensory learning styles to support the different learning styles and personality types of the students in the courses. According to such a framework, the instructor must carefully plan and prepare the material to allow students in the courses to retain the knowledge and via formative assessment in the courses continuously rethink the delivery of instruction for high quality teaching (p. 3).

The Research component helped me to become aware and understand how to sift the narrative data in the journal and to use them to always keep a focus on the quality of instruction according to the cohort in the literacy courses I was teaching. The data that emerged from the Literacy Strategy Journal demonstrate how self-reflection in a dialogic mode between the instructor and the students in the course are not scattered thoughts but a systematic framework that guides instruction in meaningful and effective ways and allow the instructor to find a center from where he could systematically improve his teaching of literacy in college courses.

\section{The Data: Qualitative Transformations in the Self-Dialogic Process}

The first significant and coherent set of data emerged in my Literacy Strategy Journal at the turning point of the semester or after the first eight weeks. In an entry dated November 10 2011, I wrote down a reflection on effective instruction coming from circling back to the theoretical and methodological framework set for the Literacy Strategy Journal. This reflection emerged from a continuous dialogue and interaction with the students in the graduate literacy course I was teaching. Students' questions and conversations in the classrooms were focused on how to deliver effective literacy instruction in K-12 schools. I wrote

Effective instruction in K-12 schools is always informed by a system in which theory, research design, data collection and analysis and assessment of a particular literacy strategy is coherently and consistently analyzed to inform good teaching in the classroom. There is no component more important than others. Teacher's intuition alone or "guts teaching" is not a very effective way of assessing students' learning; it is a spark, a serendipitous process that must be systematize and clarified with consistent data to support teacher's insights on how students learn and grow via literacy instruction (p.10).

The reflection came to the fore due, as I pointed out, because the students in the graduate literacy course were asking if intuition was part of good teaching since they observed such a behavior during their student teaching. The dialogic mode of the course was crucial to push my thoughts to the surface of the Literacy Strategy Journal and allowed me to create a dynamic triad between my self-reflective self, the content of the graduate literacy course and the voices of the students interacting with the curriculum and the mode of presentation of the content in the course (Brookfield, 1987).

This first spike of my dialogic reflective process in my Literacy Strategy Journal signaled a qualitative change in my self-reflective practice and the mode of instruction that was changing by constantly unfolding during my teaching of the graduate literacy course. The maturation of this first turning point in my dialogic reflective thinking happened at the end of the November when I was reviewing some material for an activity of different modes of representations in literacy instruction.

I was preparing a class on how to go beyond the traditional ways of teaching literacy in the content areas or the use of written and spoken responses in the teaching of literacy in K-12 schools when one of the graduate students with an Arts major pointed out that she conceived literacy as an art teacher from a broader and more complex perspective. She said that literacy for an artist is a way of reading and interpreting an experience by analyzing the language or the semiotic system of art (Fisher, 2003). The discussion simmered for a couple of days in my mind until I sat down in my office, opened my Literacy Strategy Journal and wrote 
Curriculum, instruction and learning can be systematically planned by assessing students' learning styles and personality types in order to develop a systematic understanding on how students use systems of meaning to access and acquire knowledge through different modes of representation of knowledge. This means that as an instructor I must conduct a systematic and extensive research to find material that can be supportive of teachers in school engaged in using literacy in the content areas to allow students to become literate in a complex and fast-evolving world. The idea of literacy as a complex semiotic system is something I want to explore more later on to improve the way I serve and support students in teaching literacy in the content areas in K-12 schools (p. 11).

This dialogic reflection signaled the closure of my first semester of teaching graduate and undergraduate courses in literacy in content areas and represented a new starting point and a new turning point in my journey to explore how a dialogic self-reflective process can pave new directions in teachers' professional development to prepare literacy educators to serve students in K-12 schools in the $21^{\text {st }}$ century.

\section{Discussion}

The Literacy Strategy Journal discussed in this paper is a work in progress embedded in a Bakhtinian tradition of dialogic thinking. The theoretical framework used to self-reflect deviates from the traditional idea of self-reflective practice usually adopted by educators (Hallman, 2011). My goal to keep such a journal was and still is to continue to refine self-reflective thinking to become a better teacher educator and to conceptually change the way I understand literacy in the content areas. I will support pre-service and in-service teachers to support students in K-12 schools in learning literacy in a complex society where students must read and understand the world by navigating complex semiotic systems (Hodge and Cress, 1988).

The self-reflective practice and journey within a dialogic theoretical and methodological framework is interactional and evolutionary in nature (Bakhtin, 1984). It is interactional because it does not confine my thoughts within the traditional dichotomy of self-reflective practice. It is evolutionary because self-reflective thought constantly nurture itself by attending and dynamically interacting with the thoughts of others, with the polyphony of meanings that emerge from the minds and voices of others to inform my instruction in literacy in teacher education programs in the United States (Bakhtin, 1984).

The journey discussed in this paper represents the beginning of my conceptual change in looking at literacy instruction as a complex object. The transformations that occurred are due to the voices from my students and my decision to examine these voices in the context of what it means to become literate in the $21^{\text {st }}$ century. The core of the dialogic thinking and transformations that unfolded in this paper happened because of the true nature of language in its different forms of communication and modes of delivery. As Kane (2011) argues language is the center of metacognition and critical thinking. The ability to use language in the context of literacy curriculum and instruction is crucial to give students the opportunity to see the literacy process as paramount in the education of learners in K-12 schools.

The learning journal as a vehicle for reflection was to make metacognition and critical thinking visible and more importantly an active component of self-reflection in the dialogic process that occurred in the course I was teaching. I and my students were able to create a critical dialogue on literacy without looking for the right answer but for what it means to explore the multiple levels of meanings and use of literacy in our contemporary society. Such a dialogue represents my idea of teaching and learning within a self-reflective dialogical framework where students have the opportunity to explore complex issue by co-constructing knowledge with the instructor. Also, in this model of learning consensus is not important. What it is important is to find possible models of learning and teaching literacy seen as open pedagogical framework for learning and teaching (Kane 2011).

A self-reflective practice embedded in a dialogic process has the potential to illuminate the object of reflection, literacy learning in the content areas, from many different but converging perspectives. The voices informing the dialogue on how to teach literacy in K-12 instruction can enrich our knowledge and understanding on how literacy is changing and will continue to change in a society where new and complex semiotic systems will require teachers of literacy to continuously rethink the way literacy is conceptualized and taught in K-12 schools (Angaran, 1999).

\section{References}

Angaran, J. (1999). Reflection in an age of assessment. Educational Leadership, 56(6), 71-72.

Attard, K. (2008). Uncertainty for the reflective practitioner: A blessing in disguise. Reflective Practice, 9(3), 307-317. http://dx.doi.org/10.1080/14623940802207188 
Bakhtin, M. M. (1981). The dialogic imagination: Four essays. University of Texas Press, Austin TX.

Bakhtin, M. M. (1984a). Problems of Dostoevsky's poetics. University of Minnesota Press.

Bakhtin, M. M. (1986). Speech genres and other later essays. Austin: University of Texas Press.

Bakhtin, M. M., \& V. N. Volosinov. (1986). Marxism and the philosophy of language. Cambridge: Harvard University Press.

Bolton, G. (2010). Reflective practice: Writing and professional development (3rd ed.). California: Sage.

Boud, D. (2001). Using journal writing to enhance reflective practice. New Directions for Adult and Continuing Education, 90, 9-17. http://dx.doi.org/10.1002/ace.16

Brookfield, S. D. (1987). Developing critical thinkers: challenging adults to explore alternative ways of thinking and acting. California: Jossey-Bass.

Connor-Greene, P. A. (2000). Making connections: Evaluating the effectiveness of journal writing in enhancing student learning. Teaching of Psychology, 27(1), 44-46. http://dx.doi.org/10.1207/S15328023TOP2701_10

Cornish, M. M., \& P. A. Cantor. (2008). 'Thinking about thinking: It's not just for philosophers': Using metacognitive journals to teach and learn about constructivism. Journal of Early Childhood Teacher Education, 29, 326-339. http://dx.doi.org/10.1080/10901020802470135

Epp, S. (2008). The value of reflective journaling in undergraduate nursing education: A literature review. International Journal of Nursing Studies, 45, 1379-1388. http://dx.doi.org/10.1016/j.ijnurstu.2008.01.006

Fendler, L. (2003). Teacher reflection in a hall of mirrors: Historical influences and political reverberations. Educational Researcher, 32(3), 16-25. http://dx.doi.org/10.3102/0013189X032003016

Fisher, K. (2003). Demystifying critical reflection: defining criteria for assessment. Higher Education Research and Development, 22(3), 313-325. http://dx.doi.org/10.1080/0729436032000145167

Kane, S. (2011). Literacy and learning in the content areas (3rd ed.). AZ: Holcomb Hathaway, Publishers.

Hallman, H. L. (2011). Shifting genres: a dialogic approach to reflective practice in teacher education. Reflective Practice, 12(4), 533-545. http://dx.doi.org/10.1080/14623943.2011.590343

Hodge, R., \& Cress, G. (1988). Social semiotics. Cornell University Press.

LaBoskey, V. K. (1994). Development of reflective practice. A study of preservice teachers. New York: Teachers College Press.

Moon, J. A. (2006). Learning Journals. A handbook for reflective practice and professional development. London and New York: Routledge.

Richardson, L. (2001). Getting personal: writing stories. Qualitative Studies in Education, 14(1), 33-38. http://dx.doi.org/10.1080/09518390010007647

\section{Copyrights}

Copyright for this article is retained by the author(s), with first publication rights granted to the journal.

This is an open-access article distributed under the terms and conditions of the Creative Commons Attribution license (http://creativecommons.org/licenses/by/3.0/). 